\title{
Erratum to: Description of Geodermatophilus amargosae sp. nov., to Accommodate the Not Validly Named Geodermatophilus obscurus subsp. amargosae (Luedemann, 1968)
}

\author{
Maria del Carmen Montero-Calasanz • Markus Göker • \\ Manfred Rohde - Cathrin Spröer - Peter Schumann • \\ Shanmugam Mayilraj • Michael Goodfellow • Hans-Peter Klenk
}

Published online: 1 March 2014

(C) Springer Science+Business Media New York 2014

\section{Erratum to: Curr Microbiol (2014) 68:365-371 DOI 10.1007/s00284-013-0479-2}

In the abstract provided in the original description of Geodermatophilus amargosae sp. nov., a typographical error was overlooked, the optimal growth at $2,535{ }^{\circ} \mathrm{C}$ should be read as at $25-35{ }^{\circ} \mathrm{C}$. In addition, the term "pleiotropic" used in the Results and Discussion section is incorrect. The correct term is "pleiomorphic".

The online version of the original article can be found under doi:10.1007/s00284-013-0479-2.

M. C. Montero-Calasanz $(\bowtie) \cdot$ M. Göker · C. Spröer ·

P. Schumann - H.-P. Klenk (ه)

Leibniz Institute DSMZ - German Collection of Microorganisms and Cell Cultures, Inhoffenstraße 7B, 38124 Brunswick,

Germany

e-mail: mmc11@dsmz.de

H.-P. Klenk

e-mail: hpk@dsmz.de

M. C. Montero-Calasanz

IFAPA - Instituto de Investigación y Formación Agraria y

Pesquera, Centro Las Torres-Tomejil, Ctra. Sevilla-Cazalla de la

Sierra, Km 12.2, C.P. 41200 Alcalá del Río, Sevilla, Spain

M. Rohde

HZI - Helmholtz Centre for Infection Research, Inhoffenstraße

7, 38124 Brunswick, Germany
S. Mayilraj

MTCC-Microbial Type Culture Collection \& Gene Bank, Institute of Microbial Technology, Chandigarh 160036, India

M. Goodfellow

School of Biology, Ridley Building, Newcastle University,

Newcastle upon Tyne NE1 7RU, UK

e-mail: m.goodfellow@ncl.ac.uk 